\title{
Terrorism, Religious Intolerance and Ethnic Conflict Issues in the National Education Policy - 2010 of Bangladesh: An Exploratory Study
}

\author{
Nur Muhammud Sajjadul Hoque Sumon* \\ Department of Anthropology, University of Chittagong \\ Bangladesh
}

\begin{abstract}
Education is considered an instrument to combat the problems of terrorism, religious antagonism and ethnic intolerance. Bangladesh has been experiencing its share of these problems along with other South Asian countries. The recent adoption of the National Education Policy (NEP) of 2010 has been an opportunity to consider how the education system can help address these problems. However, a lack of consensus about interpretations of the issues of terrorism, ethnicity and intolerance among the major political parties and different religious groups has stymied this effort. NEP-2010 may be seen as a victim of politico-religious disagreements among stakeholders, especially due to a strong position from a part of the Islamic community. The three issues are interrelated in the sense that, firstly, they emerge from a lack of respect for diversity, and secondly, the problems arise as much from ideological views, as from social and economic conditions. By considering these realities, this paper will examine how the problems have been recognized and attempted to counter in NEP. Empirical dataon people's perception on NEP and the three issues have been used to buttress the arguments.
\end{abstract}

Keywords: National Education Policy 2010, terrorism, religious intolerance, ethnic intolerance, education

\section{Introduction}

Every country inthe world, in varying degree, is experiencing the problems of terrorism, religious antagonism and ethnic intolerance. Terrorism ${ }^{1}$, religious intolerance ${ }^{2}$ and ethnic intolerance ${ }^{3}$ transcend political borders in the era of globalization. Moreover, religion has often become acauseof discord rather than unity. The minority communities are experiencing suppression in many situations by a 'cultural homogenization' process both from inside and outside of their countries. A 'majoritarian' view dominates the practice of democracy. Likewise, the idea of 'plurality' of nationhood, religions, or ethnicity is more rhetorical than real in the countries of South Asia. ${ }^{4}$ 
In Bangladesh, attacks on courts of law all over the country and other violent acts by Islamic extremists, and the rise of Islamic militant groups like Jamaatul Mujahedin Bangladesh (JMB), recently banned Hijbut Tahrir, and previously banned Hijbut Tawhid are apparent manifestations of terrorism. The attack on the Opposition Leader of Parliament in August 2004 that caused about two dozen deaths wasalso justified by political motives.

The issue of ethnic intolerance, particularly the conflict in Chittagong Hill tracts (CHT) between the Bangalee ${ }^{5}$ settlers and indigenous community, suppressing the rights of indigenous communities, has festered for a long time.Thus, religious intolerance appears to have grown to some extent in Bangladesh. A case in point is the need to protect the minorities' security by police during their religious festivals.

As a vulnerable country, Bangladesh has to pay special attention to the problems of terrorism, religious conflict and ethnic intolerance. The process of formulation and adoption of NEP-2010 has brought to the fore strong opposition from the Madrasah, especially the Qwomi (unrecognized and independent) ones, about some proposals in the policy. This situation has arisen even though the policy has not tried to address the problems noted above directly. Disagreements among the policy makers based on partisan politics have made it difficult to take a clear stand on various issues. There have been disagreements about concepts and practical measures about terrorism, protection of minorities, and the rights of ethnic groups from the top level of policy makers to the level of the general public.

Against the above backdrop, the purpose of this paper is to explore the reflection of the issues of terrorism, ethnic conflicts and religious intolerance in the NEP-2010 of Bangladesh. The paper particularly explores how education can be a factor for both the growth of, and addressing terrorism, ethnic conflict and religious intolerance. A survey was carried out to portray how the policy is perceived by different kinds of respondents regarding countering these problems. The paper presents a sketch of the state of terrorism and religious and ethnic intolerance in Bangladesh in recent years. It then examines on the basis of a sample survey the views of a select cross-section of respondents about what the issues are and how these could be addressed in the education policy.

\section{Glimpse of Terrorism, Religious Intolerance and Ethnic Conflict in Bangladesh}

Bangladesh has remained vulnerable to growing threats of terrorism and religious and ethnic intolerance. It may be argued that there has been relative stability since the Awami League-led coalition assumed power in 2009; but there has been upsurge of violence from time to time, especially during the opposition movement in 2013 regarding the process of parliamentary election.

\section{Terrorism}

Terrorism became a serious concern for Bangladesh especially after JMB's rise. It has been reported that there are over 50 Islamist militant-extremist groups ${ }^{6}$ in Bangladesh 
(Barakat, 2011). A partial list of terrorist violence in recent years include: bomb attack on Udichi, a progressive cultural group (Jessore, 1999, causing 10 deaths and 50 injuries); the grenade attack on an opposition rally aimed at the then opposition leader Sheikh Hasina, injuring her and 200 others and killing at least 23 (21 August 2004); 500 synchronized bomb blasts in all but one of 64 districts of the country on 17 August, 2005; a series of suicide bomb attacks all over the country on 7 December 2005 killing eight people and injuring many. The list could further go on.

South Asia Terrorism Portal (SATP) gives some data on 'Fatalities-Islamist Terrorism, 2005-2012' in which it indicates the casualties of terrorism in Bangladesh. It reports that from 1999 to 2005, there were 25 terrorist attacks in Bangladesh leading to 202 people being killed and about 1800 people injured (Barakat, 2011). From 2005 to 2012, according to $\operatorname{SATP}(2011)$, there have been 65 fatalities and many more injuries due to religious violence.

The terroristgroups appear to be inspired by a misguided ideological motivation. They are from diverse educational background, both general and faith based. When a group or organization is banned by the authorities, they re-emerge and try to carry on their activities by another platform and banner.

\section{Religious Intolerance}

Religious intolerance, religion-motivated violence, the violation of minority rights have remained a concern, ever since the assassination of the founding and the first Prime Minister of the country Sheikh Mujibur Rahman on 15 August 1975 in a military coup and military rulers began to rule the country. The authoritarian rulers tried to gain legitimacy by appealing to the religious sentiments of the people by altering the secular character of the national constitution and for a period renaming the country as the Islamic Republic of Bangladesh.

Given such change, the religious minorities of the country feel, as statements and expressions by organizations of minorities indicate, that their right to life, liberty and worship are under threat. In the beginning of 2011, the theft of a large amounts of gold and money from the Dhakeshwari Temple, Bangladesh's 'national temple', in the capital city of Dhaka, left the Hindu community deeply shocked and traumatized (Hindu American Foundation [HAF], 2011). A Harinam Sankirtan, a Hindu religious festival, was attacked in Sunamganj in March 2011. In April 2011, International Society for Krishna Consciousness (ISKCON) temple was attacked and a copy of the Bhagavad Gita burnt in Sylhet district (HAF, 2011). A group of Muslims carrying weapons attacked a Hindu temple the Narayan Shiva Mandir in Khasa Pandith Para of Beani Bazar in Sylhet District on April 2, 2011. In September, the Dainik Azad,reported that a temple dedicated to the Goddess Durga in Bandarban district was attacked and destroyed and a deity of Durga Puja festival was destroyed in Narayanganj, according to the Ittefaq (HAF, 2011). On September 29, 2012 
mobs demolished 12 Buddhist temples and monasteries and more than 50 houses in Ramu Upazila at Cox's Bazar. Two monasteries and a Hindu temple in Chittagong were destroyed and two monasteries at Ukhia and five houses at Teknaf Upazila were torched around the same time. ${ }^{7}$

These anecdotes, not necessarily all verified and authenticated, and reported by aggrieved groups, do not constitute sufficient evidence regarding the national situation or provide a pattern or trend of what has been happening over time. Nonetheless, they clearly indicate that there is a problem of religious intolerance, violation of minority rights, and ethnic conflicts which have directly or indirectly fuelled terrorist activities.

\section{Ethnic Intolerance}

According to Human Rights Report 2011 on Indigenous Peoples in Bangladesh, 51 incidents of Human Rights violation happened in 2011 all over the country (Barman \& Neo, 2012, p. 126). A report of Parbattya Chattagram Jana Shanghati Shamity (PCJSS) on Human Rights claimed there were 648 violations of rights against the indigenous people in 2009 and 2010. The number of such violations in 10 years, from 1998-2008, were reported to be 4,755 (PCJSS, 2012). The common elements in these cases are that the alleged violators are individuals or groups of the majority community and the victims were religious and ethnic minorities.

\section{Conflict, Violence, Terrorism and Education}

Terrorism as well-planned and coordinated targeting of a specific group is not necessarily the result of lack of education, but education may be a factor in one's inclination to support or engage in terrorist activities. In the case of Sri Lanka, educational level of individuals or groups does not seem to influence the involvement of individuals in ethnic conflict and civil war between the Tamil and the Sinhala communities (Ibarra, 2011, p. 6). Russell and Miller (as cited in Hudson, 1999, p. 48) found that around two thirds of those who engaged in terrorism had university education. Krueger and Maleckova (as cited in Avihai, n.d.) found that socio-political motivation rather than lack of education was responsible for terrorism.

If an ideological orientation is the problem, it can be argued that this has to be countered ideologically through education (Ali, n.d., pp. 3-5). Here lies the main potential link between education and terrorism. In this regard, United Nations counter-terrorism implementation task force (CTITF) emphasized education as the effective means of countering terrorism (United Nations, 2011). National Strategy for Combating Terrorism of USA also stressed on education as a strategy (NSCT, USA 2006). The North Atlantic Treaty Organisation (NATO)'s policy guideline on counter terrorism considers education as a means to counter terrorism (NATO, 2012). 
In NEP-2010, education is considered a means of cultivation of human values ( $p$. 8 ) and education is expected to help build a society without divisiveness...eradicating communalism (Foreword, p. 5); people will have respect "for their own religion as well as for other's faiths" (p. 8). The policy also asserts that "Education willhelp them to grow up as non-communal..." (p. 8). The same hope is expressed in objective 3 of the policy. Education is seen as a tool "to remove socio-economic discrimination irrespective of race, religion and creed and toeradicate gender disparity; to develop non-communalism, friendliness, global fraternity, fellow-feeling and respect for human rights" (p. 8); "to show tolerance for different ideologies for the development of a democratic culture..." and "to establish a sense ofequal status amongst all citizens" (p. 9).

\section{Study Question and Methodology}

Starting from the premise that education system - its objectives and how it is carried out - influences the underlying conditions and the prevalence of religious and ethnic conflicts which are sometimes manifested in acts of terrorism, the study investigates how the national Education Policy 2010 of Bangladesh addresses this nexus of religious conflict, ethnic intolerance and terrorism.

The research question is attempted to be answered first, by a textual analysis of the policy to show if and how the question is noted and identified in the policy and how the question is proposed to be addressed as a problem. Secondly, a survey of some 500 respondents is undertaken to determine their perceptions and views about the Education Policy and how it addresses the interrelated problems of religious conflict, ethnic violence and terrorism. The sample was purposively selected from educational institutions of different types in four urban locations - Dhaka, the capital city, and Chittagong, Rajshahi and Sylhet, all major metropolitan areas (Table 1). Besides a questionnaire administered to the selected sample, expert interviews were held with ten people, and eight focus group discussions were conducted with teachers and students separately in the four study cities. The questionnaire consisted of ten questions. Each of the questions contained four options for answers on an opinion scale, except for one with three options. The questions related to three broad categories - a) understanding or concept of respondents about terrorism, religious intolerance and ethnic conflict; b) concept and knowledge about education and education policy; and c) if and how education policy influenced the three interrelated problems.

Out of the 500 in the sample, 463 respondents (students and teachers from primary to university levels) were from educational institutions including religion based educational institutions (411 respondents were from general educational institutions and 52 were from Madrasah) and 37 respondents were from a pool of politicians, journalists, guardians and people involved in formulating the education policy. The proportion of students from general educational institutions and Madrasah roughly represented their proportions in 
the total student body. For interviews, only education related experts were selected for obvious reasons. For FGD, the teachers and students were selected from among students of higher grades and more senior teachers with longer experience in teaching. The educational institutions were chosen on the basis of good academic reputation in each city.

Table 1

Numbers and Categories of Respondents of Questionnaire

\begin{tabular}{|c|c|c|c|c|c|c|}
\hline $\begin{array}{l}\text { Sector } \\
\text { Area }\end{array}$ & $\begin{array}{l}\text { General Education } \\
\text { Institution } \\
\text { (students and } \\
\text { teachers ) }\end{array}$ & $\begin{array}{l}\text { Madrasah(students } \\
\text { and teachers ) }\end{array}$ & $\begin{array}{l}\text { O. } \\
\text { : } \\
\text { : }\end{array}$ & 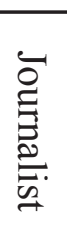 & 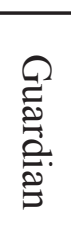 & $\begin{array}{l}\text { Peoplerelated } \\
\text { to NEP }\end{array}$ \\
\hline Dhaka & 111 & 18 & 2 & 2 & 3 & 3 \\
\hline Chittagong & 100 & 12 & 2 & 2 & 3 & 2 \\
\hline Rajshahi & 103 & 10 & 2 & 2 & 3 & 2 \\
\hline Sylhet & 97 & 12 & 2 & 2 & 3 & 2 \\
\hline Total & 411 & 52 & 8 & 8 & 12 & 9 \\
\hline
\end{tabular}

Data collection was subject to limitations. In spite of the effort to select the sample to include people with some knowledge and understanding of the national education policy, many were found to have little understanding of or familiarity with the policy and had no opinion about it. In this sense, it was an opportunistic sample that may not be an adequate representation of the perceptions and views of the larger population.

\section{Overview of NEP 2010}

The first attemptto formulate an education policy was initiated by Bangabandhu Sheikh Mujibur Rahman, the then Prime Minister, in 1972, under the leadership of Dr. Qudrate-Khuda, a renowned scientist and educationist. The report was completed in 1974, but before decisions were taken about its implementation, Bangabandhu was assassinated in August 1975 in a military coup. Since then various governments formed commissions and committees to prepare an education policy. Various documents were prepared, but none were taken up for systematic implementation mainly because of frequent political changes and a lack of consensus about some of the important recommendations. The political government, led by the same coalition of parties as the current one formed another commission in 1996 which prepared 'Education Policy 2000'. It was approved by the national parliament, but when a different political coalition formed the government in 2001, 
the policy was shelved. In 2008, the Awami League-led coalition returned to power and the process of reviewing and updating the national Education Policy 2010 was initiated (MoE, 2011).

National Education Policy 2010 included 24 goals and objectives emphasizing morality, creativity and production oriented education; overcoming inequity regarding gender, religion and ethnicity; promoting information and communication technology (ICT); competency in mathematics and science; and the same core curriculum and syllabus for all streams of education. The distinctive features of this education policy relevant to this research are as follows:

- The policy seeks to bring all students of the country, irrespective of their religion, gender, and physical limitations, socioeconomic position and geographic locations under a common system (pp. 1, 25, 57, \& 72).

- One-year pre-primary education for children over five years old would be introduced (p. 4).

- Compulsory and free primary education would be extended up to classVIII from classV (p. 6) and secondary education to classXII with common core curriculum and syllabus (p. 13).

- The policy is non-communal, but there would be compulsory subjects of religion and ethics for students up to classVIII (Rezwan, 2009; Guru, 2010).

- On Madrasah education, it is provided that students of primary and secondary level study the common curriculum and syllabus of general education (MoE, 2011, p. 6).

- Religious and moral education, value education, building good character, upgrading curriculum content on Islam, Hindu, Christian and Buddhist religion; and a new curriculum for indigenousreligions is also proposed (MoE, 2011, pp. 21-22; Roy, 2011).

- Education at the primary level for indigenous students in their mother tongues was recommended (MoE, 2011, p. 5; Rezwan, 2009).

Of the three issues, religious and ethnic intolerance were partially addressed by the education policy but the issue of terrorism was ignored. The following tables provide a schema of the new education policy. 
Table 2

Issue of Religious and Other Forms of Intolerance in National Education Policy

Issue Chapter Page Title Description

Education: accomplished human beings with ethical

$1 \quad 1$ Aims and

Objectives

7

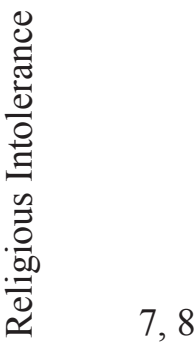

21

22, Higher

25 Education

24

57 25

61
Teachers'
Training

Status,

Religious

and Moral

Education

Rights and

Responsibilities of Teachers
The learners will become rational and intellectually perceptions, who have respect for their own religion as well as for others' faiths. Chapter 2 strategy number 4 also addresses this issue.

The objective of religious and moral education is to impart knowledge about the respective religions of the learners, as well as building of moral character of the learners. Major religions - Islam, Hinduism, Buddhism, and Christianity -would be taught to their respective followers. Indigenous people and other communities who have different religious faiths will have opportunities to learn about their own religion.

Universities cannot discriminate among students in respect of race, religion, cast (p.25). Chapter 22 about students' welfare and counseling also has several related points.

To encourage them to create in teaching equal opportunities for all students, irrespective of religion, race and socio-economic conditions.

The major duties of the teachers include inspiring and encouraging the students to respect his/her own religion and of others; to build them up as patriotic, good citizens free from superstitions.

(Source: MoE, 2011) 
Table 3

Issue of Ethnic Intolerance in National Education Policy

\begin{tabular}{|c|c|c|c|c|}
\hline Issue & Chapter & Page & Title & Description \\
\hline \multirow{6}{*}{ 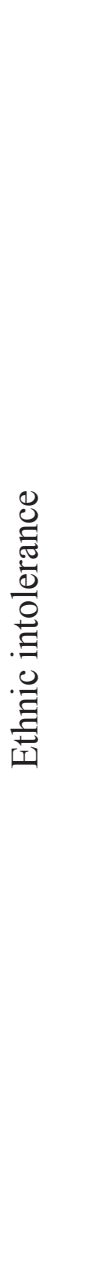 } & 1 & 3 & $\begin{array}{l}\text { Education: Aims } \\
\text { and Objectives }\end{array}$ & $\begin{array}{l}\text { To promote and develop the languages and } \\
\text { cultures of the indigenous and small ethnic } \\
\text { groups; }\end{array}$ \\
\hline & 2 & 4-5 & $\begin{array}{l}\text { Pre-primary } \\
\text { and Primary } \\
\text { Education, } \\
\text { (Aims and } \\
\text { Objectives) }\end{array}$ & $\begin{array}{l}\text { Equal opportunities will be created to } \\
\text { ensure access of all sections of children to } \\
\text { primary education irrespective of ethnicity, } \\
\text { socioeconomic conditions, physical mental } \\
\text { challenges and geographical differences. }\end{array}$ \\
\hline & 8 & 24 & $\begin{array}{l}\text { Higher Education } \\
\text { (Aims and } \\
\text { objectives) }\end{array}$ & $\begin{array}{l}\text { Measures will be taken to provide residential } \\
\text { facilities, special help and scholarships for the } \\
\text { children of freedom fighters, of small ethnic } \\
\text { communities and socially backward groups. }\end{array}$ \\
\hline & 17 & 42 & $\begin{array}{l}\text { Fine Arts and } \\
\text { Crafts Education }\end{array}$ & $\begin{array}{l}\text { Special opportunities will be created for students } \\
\text { belonging to backward classes and small ethnic } \\
\text { groups. }\end{array}$ \\
\hline & 22 & 54 & $\begin{array}{l}\text { Students' Welfare } \\
\text { and Counseling }\end{array}$ & $\begin{array}{l}\text { All human beings, irrespective of sex, race, } \\
\text { ethnic roots, socioeconomic situations and } \\
\text { physical or mental conditions are eligible to } \\
\text { enjoy equal human rights. }\end{array}$ \\
\hline & 24 & 58 & $\begin{array}{l}\text { Teachers' Training } \\
\text { (Aims and } \\
\text { Objectives) }\end{array}$ & $\begin{array}{l}\text { To help teachers acquire efficiency in delivering } \\
\text { education to the students of disadvantaged } \\
\text { community and small ethnic groups and the } \\
\text { disabled learners by sincerely responding to } \\
\text { their special needs. }\end{array}$ \\
\hline
\end{tabular}

(Source: MoE, 2011)

The above analysis shows that there is no direct mention about terrorism. Nevertheless, there are implicit allusions to religious conflicts and ethnic intolerance in NEP.

\section{Analysis of Survey Data and Findings}

The survey of perceptions and views of the sample of students, teachers and informed citizens was designed to explore several questions:

- Are religious intolerance, ethnic conflicts and terrorism significant problems in Bangladesh?

- Are people familiar with NEP and its dealing with the problems of terrorism, reli- 
gious intolerance and ethnic conflicts?

- Is education in general and NEP in particular, an instrument to deal with the problems of terrorism and ethnic and religious conflicts?

- What is NEP's position on conflicts and terrorism?

- Can NEP counter communalism and should NEP attempt to counter communalism?

Of the sample population, $72 \%$ respondents thought terrorism, religious conflict and ethnic intolerance are problems for Bangladesh; $16 \%$ did not see these problems to be severe, and 1\% thought these problems did not exist in Bangladesh at all (Figure 1). About $53 \%$ respondents shared the view that they are concerned about the issues of terrorism and religious and ethnic intolerance; 37\% thought about the issues sometimes; and 10\% were not concerned about these problems (Figure 2).
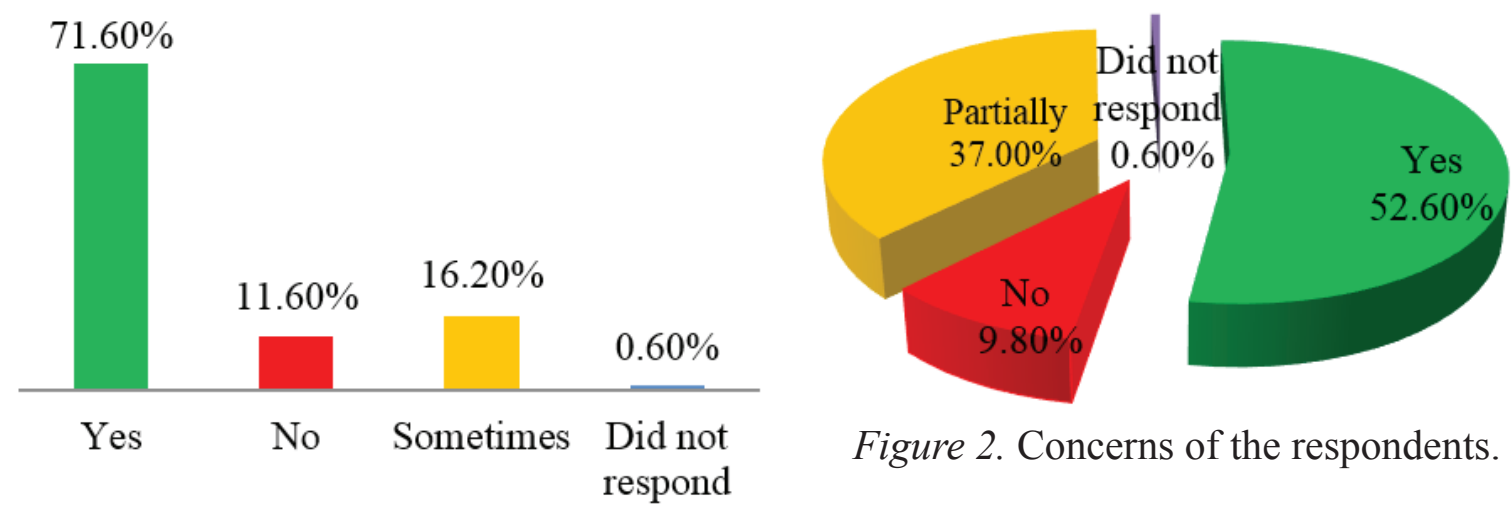

Figure 2. Concerns of the respondents.

Figure 1. Comments about terrorism.

Focus group discussions and interviews shed light on the views and perceptions of the respondents which were not reflected in the aggregate results shown in Figure 1. More of the Madrasah teachers and students did not consider terrorism, religious conflicts, and ethnic intolerance as problems. Some of them refused to enter into discussion about these issues and thought that discussing these problems showed an inclination to spread secularism and undermine Islam as the dominant ideology. An inference could be drawn that the proponents of Madrasah education saw education as a means of propagating their own religious ideology.

Is education in general the instrument to counter terrorism and conflict and how knowledgeable people are about NEP? An overwhelming majority of the respondents (91\%) regardededucation as one of the important means to counter the problems of religious and ethnic tensions and their manifestation in terrorist activities. Only 3\% of respondents answered 'no' to those questions and more than 5\% thought education could be a partial solution (Figure 3). 


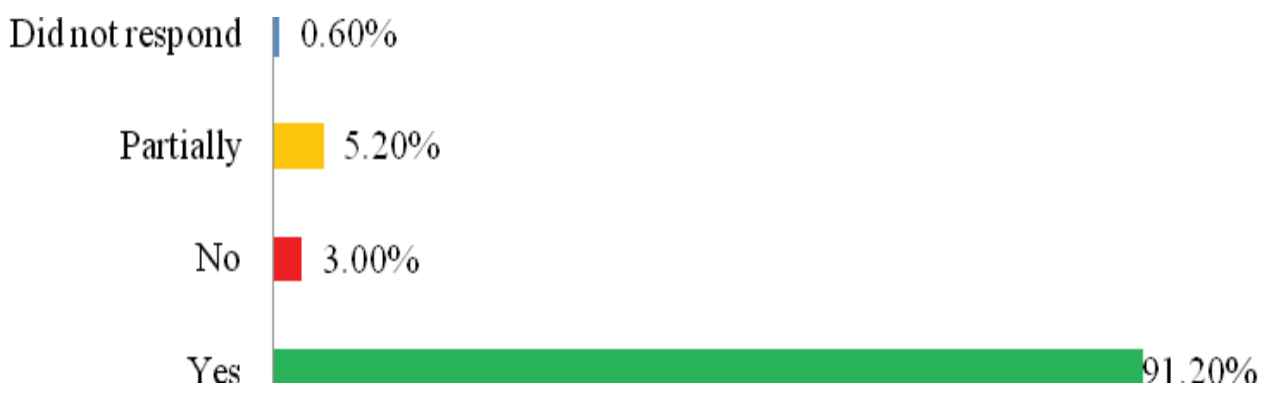

Figure 3. Percentages indicating education as an instrument to counter conflict and terrorism.

Majority of respondents, including teachers and students, were found not acquainted with NEP. Only a little over a third (37\%) reported some familiarity with NEP. However, $47 \%$ respondents said they were partially aware of the problems and possible link with NEP (Figure 4).

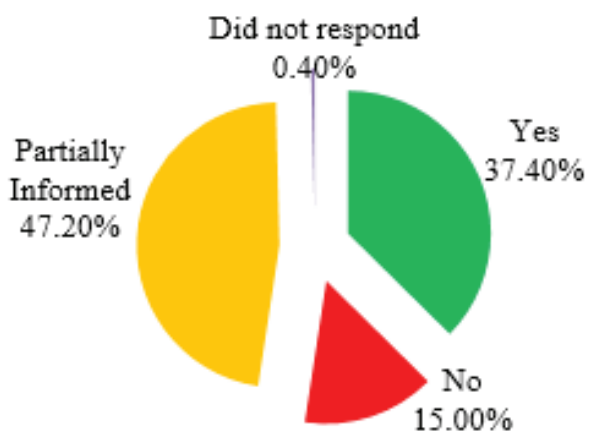

Figure 4. Percentages of respondents knowledgeable about NEP.

A large majority of the respondents thought that NEP either did not address or only partially address religious intolerance, ethnic conflicts and terrorism issues. Here, the largest number ofrespondents (44\%)felt that NEP-2010 addressed the issues partially, whereas almost one-third (30\%) had the view that these concerns were not given attention by the policy. Only $15 \%$ people expressed the view that NEP addressed the problems adequately (Figure 5).

$$
\square \text { Yes } \square \text { No } \square \text { Partially } \square \text { Did not respond }
$$

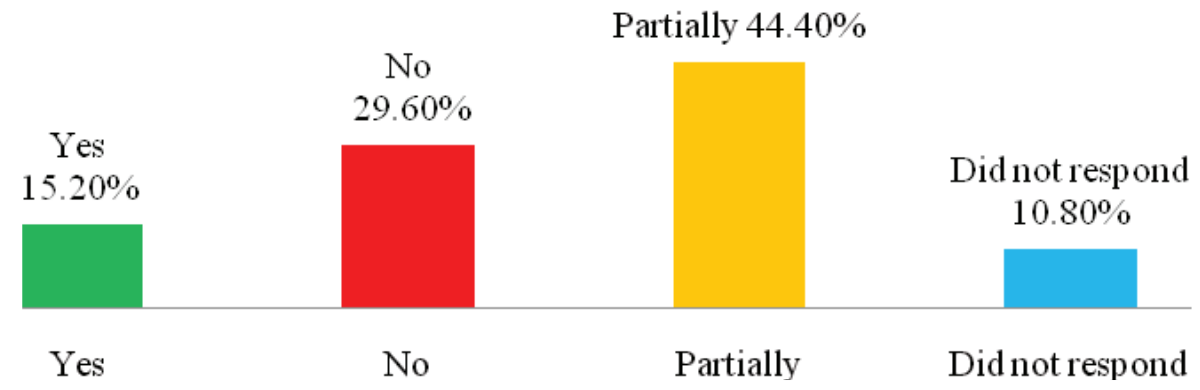

Figure 5. Respondents indicating NEP addressed problems of conflict and terrorism. 
The majority of the respondents did not think NEP addressed the issues of conflict, violence and terrorism. In this scenario, could NEP become an effective instrument, if it addressed these problems?

About $44 \%$ of the respondents did not consider NEP-2010 an adequate instrument to counter terrorism and conflict. About one-third thought this could play some role and $13 \%$ saw no role for it (Figure 6).

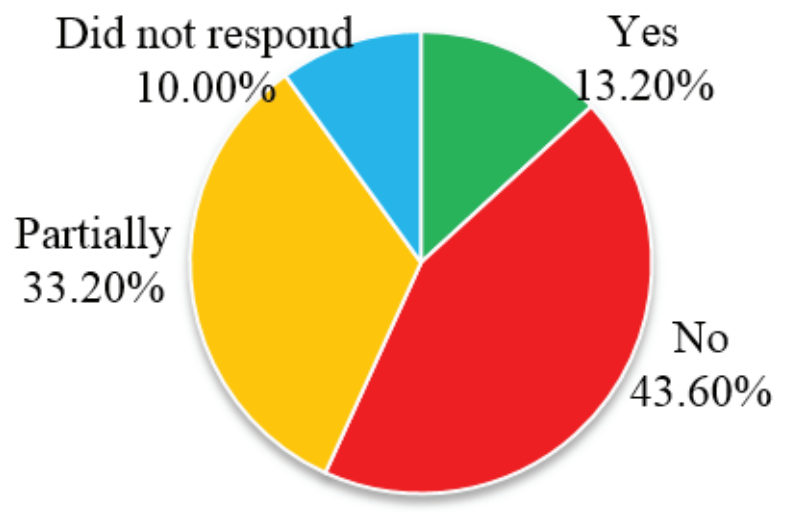

Figure 6. Percentages of respondents indicating NEP as an adequate instrument to tackle conflict and terrorism.

Since religious intolerance is a concern and a source of conflict and potential progenitor of terrorism, a pertinent question is what the stand is of NEP on religion; particularly, whether it accords a special position to Islam, the faith of the large majority in Bangladesh, and a matter of special interest to religious groups and religion-inspired political parties in the country.

This study explored what the respondents thought about the impartiality of NEP regarding different religious faiths. About half of the respondents thought that the present education policy was not biased towards any religion. On the other hand, $17 \%$ thought the education policy reflected a bias towards religion and $21 \%$ were of the view that NEP was partially biased. The overall view appears to be split in the middle, about half thought the policy was neutral about religion and another half considered it influenced by a religious bias to a large degree or at least partially (Figure 7).

FGD and interviews indicated that, most of the respondents from the general education system thought that the NEP was neutral about religion, whereas students and politicians involved with various forms of minority rights movement thought that the policy was biased towards the religion of the majority, Islam. On the other hand, respondents specially from the Madrasah education system thought that the policy was 'religion- less' and designed to propagate secularism, a matter of grave concern to them. 


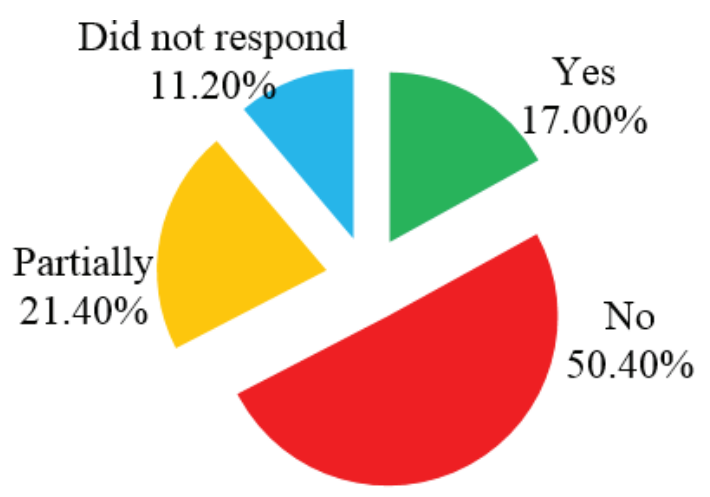

Figure 7. Percentages indicating NEP's degree of bias towards religion.

A range of views, split three-ways almost evenly, was expressed by respondents about communalism and the role of NEP. About a third thought education could help combat communalism (meaning allegiance to a religious community and antipathy to those belonging to other religious communities); another third were categorical in denying a role of NEP in this regard; while almost another third saw some role and responsibility of NEP in addressing communal prejudices and biases (Figure 8).

Qualitative probe through interview and FGD suggested that the respondents from the general education system believed that the NEP could help foster communal harmony by making education content, methods and practices deliberately non-communal. On the other hand, some education specialists thought that this policy cannot promote a non-communal system; the policy itself being biased towards a particular religion, could not promote a non-communal education culture, practice and values.

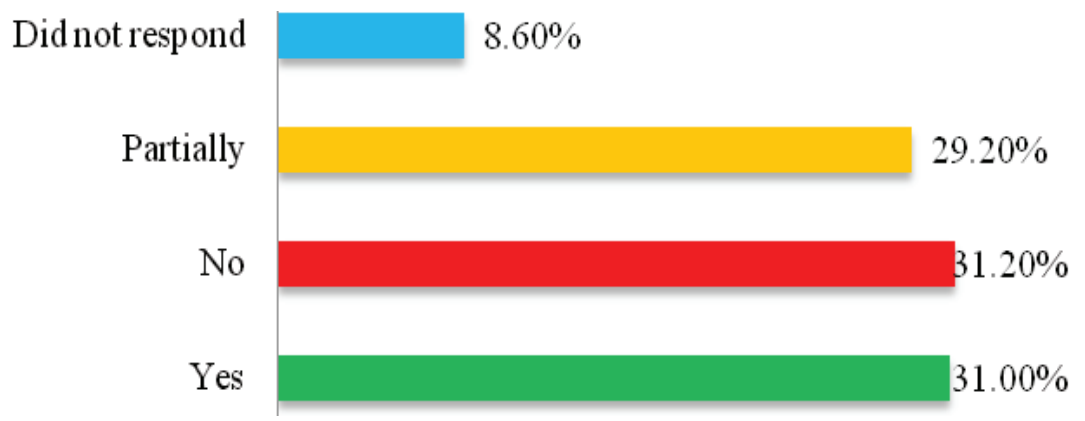

Figure 8. Percentages indicating NEP playing a role in combating communalism.

The respondents appeared to have great expectations about NEP and the education system becoming an instrument for society to combat religious intolerance, ethnic conflicts and terrorist violence. An overwhelming majority of the respondents (85\%) wanted the education system to play this role (Figure 9). 


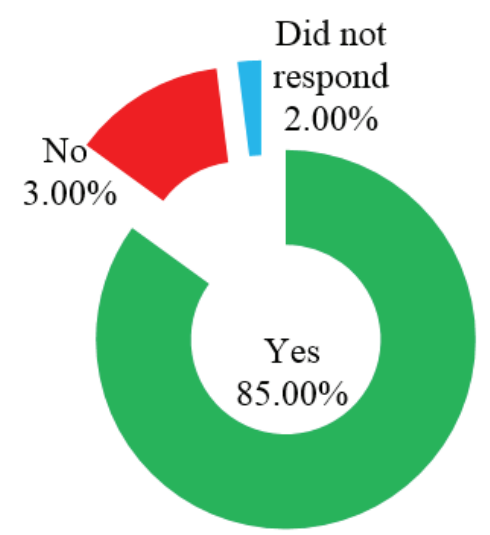

Figure 9. Percentages of respondents supporting NEP's role in combating conflict and terrorism.

To counter the problems of conflict and violence in Bangladesh, the respondents including the experts seemed to believe that the inclusion of these topics in NEP would bring a positive change in the country. These expectations and a high degree of confidence in the education system in this regard appeared to be in contradiction to other views expressed by the respondents, such as those about the extent NEP at least recognised the problem and attempted to deal with these and whether the education system and education policy could actually help combat conflicts, violence and terrorism. The respondents, it appeared, were making a distinction between what the education system and education policy could actually do and what they thought the system and policy should do. This distinction seemed to represent a latent hope and faith of people in education to solve society's problems, even though empirical evidence did not fully justify such hope and faith.

\section{Concluding Remarks}

The failure of the state in satisfying the basic needs of the people, growing criminalization of economy and politics, growing inequality in the society, increasing youth unemployment, lack of people's confidence inmainstream democratic political leadership, communalization of culture and education, public religiosity favoring the faith espoused by the majority, the retreat of secular values, and the global environment that fuel these trends --- all are factors which contribute directly and indirectly to the growth of religious intolerance and ethnic conflicts. These trends create the conditions for terrorism. How education can be harnessed directly or indirectly to mitigate and combat the creation of conditions generating religious and ethnic conflicts and their manifestation in terrorism will remain an issue of debate for education policy-making and educational practices.

As the UNESCO Constitution put it, “... since wars begin in the minds of men, it is in the minds of men that the defenses of peace must be constructed" (UNESCO, 1945) wherethe education system, in the broadest sense, provides the bricks and mortar for these defenses. 


\section{Notes}

1 United Nations defines terrorism, by Security Council Resolution 1566 (2004) as "criminal acts, including against civilians, committed with the intent to cause death or serious bodily injury, or taking of hostages, with the purpose to provoke a state of terror in the general public or in a group of persons or particular persons, intimidate a population or compel a government or an international organization to do or to abstain from doing any act." Sixteen main elements of terrorism have been identified by Schmid and Jongman (2005, p. 28).

2 Religious intolerance is the absence of tolerance to religious activities and attitudes of people from another religion. A sophisticated definition comes from Andrew Cohen (2004, p. 69):

"An act of toleration is an agent's intentional and principled refraining from interfering with an opposed other (or their behaviour, etc.) in situations of diversity, where the agent believes she has the power to interfere".

3 "Ethnic intolerance refers to a denial of access to resources and rights to other ethnic groups" (Blagojevic, 2009, p. 4). It also refers to feelings and acts of prejudice and hostility towards an ethnic group in various degrees. Here in this paper, it is defined as refusal to recognize equal opportunities, and justification of dominance or violence by negative sentiments/ activities directed against ethnic/racial/religious groups, arising from the prejudices towards those groups, and occurring in public discourse including media, any form of verbal harassment (verbal abuse, threats, and disdain), encouragement of ethnic intolerance (hate speech), and incitement to discriminate, be hostile, and engage in violence.

4 Afghanistan is a prominent victim of terrorism, arising from geo-political and military situation as well as religious and ethnic intolerance. These problems are devastating internal harmony, progress and the unity of Afghanistan. Pakistan is also facing similar problems. India is facing the problem of internal insurgency of Maoism, ULFA etc. The minority Muslim are subject to violence and discrimination from the majority Hindus.

5 Bangalee is the term used to describe Bangladeshi nationals as defined by the Constitution of Bangladesh. Indigenous people living in Bangladesh are also, therefore, Bangalee, but in popular discussion and perception, the term excludes ethnic minorities and is used in reference to the mainstream non-indigenous population.

6 For details refer to Barakat (2011)

7 For details, see en.wikipedia.org/wiki/2012_Ramu_violence (accessed on 19 January 2014).

\section{References}

Ali, M. B. (n.d.). Ideological response to terrorism and extremism. Retrieved from http:// www.pvtr.org/pdf/Ideology\%20Response/Ideological\%20Response\%20to\%20Terroris $\mathrm{m} \% 20$ and $\% 20$ Extremism.pdf

Avihai, H. (n.d.). Poverty or lack of education and terrorism: Between theory and practice. Retrieved from http://www.skyjack.co.il/documentsandreports-poverty-lack-ofeducation-and-terrorism.htm

Barakat, A. (2011). Economics of fundamentalism and the growth of political Islam in Bangladesh. Retrieved from http://www.secularvoiceofbangladesh.org/article\%20by\%2 0Abul\%20Barkat.htm

Barman, D. C., \& Neo, M. S. (Eds.). (2012). Human rights report 2011 on indigenous peoples in Bangladesh. Dhaka, Bangladesh: Kapaeeng Foundation. 
Blagojevic, B. (2009).Causes of ethnic conflict: A conceptual framework. Journal of Global Change and Governance, 3(1), 1-25.

Cohen, A. J. (2004). What toleration is. Ethics, 115(1), 68-95.

Guru. (2010). Bangladesh approved the National education policy, 2010 for unified education system. Retrieved from http://gurumia.com/2010/06/01/bangladesh-approvedthe-national-education-policy-2010-for-unified-education-system/

Hindu American Foundation. (2011). Human rights in Bangladesh: Excerpts from Hindus in South Asia and the diaspora, 2011. Retrieved from http://www.hafsite.org/humanrights-issues/human-rights-bangladesh-excerpts-hindus-south-asia-and-diaspora-2011

Hudson, R. A. (1999). The sociology and psychology of terrorism: Who becomes aterrorist and why? Washington, DC: Federal Research Division Library of Congress.

Iberra, R. (2011). Modernization through education: The answer for combating terrorism? (Post Graduate thesis). Monterey, CA: Naval Postgraduate School.

Ministry of Education. (2011). National education policy, 2010. Dhaka, Bangladesh: Author.

North Atlantic Treaty Organization. (2012, May 21). NATO's policy guidelines on counterterrorism: Aware, capable and engaged for a safer future. Retrieved from http://www. nato.int/cps/en/natolive/official texts_87905.htm

Parbattya Chattagram Jana Shanghati Shamity. (2012).Human rights violations (19982009). Retrieved from http://pcjss cht.org/At\%20A\%20Glance\%20\%281998-2010\%29. php

Rezwan. (2009). The proposed education policy in Bangladesh. Retrieved from http:// rezwanul.blogspot.com/2009/11/proposed-education-policy-in-bangladesh.html

Roy, G. (2011). Education commission 2010. Retrieved from http://www.slideshare.net/ gtmroy/education-commission-2010

Schmid, A. P., \& Jongman, A. (2005). Political terrorism. Piscataway, NJ: Transaction Publishers.

South Asia Terrorism Portal. (2011). Fatalities - Left-wing extremism 2005 - 2012. Retreivied from http://www.satp.org/satporgtp/countries/bangladesh/database/Fatalities$\% 20$ Left-wing\%20Extremism\%202010.htm

UNESCO. (1945). UNESCO constitution. Retrieved from http://portal.unesco.org/en/

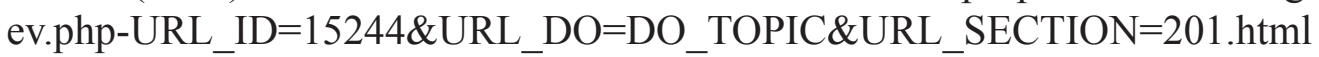

United Nations. (2011). Secretary-General's symposium on international counter-terrorism cooperation. New York, NY: United Nations Headquarters.

NSCT, USA. (2006). National strategy for combating terrorism. Washington, DC: The White House. 